\title{
THE EFFECT OF PLOUGH TILLAGE ON PRODUCTIVITY OF RATOONING RICE SYSTEM AND SOIL ORGANIC MATTER
}

\author{
Du, P. ${ }^{1, \#}-$ LUO, H. W. ${ }^{3 \#}-$ HE, L. X. ${ }^{3 \#}-$ MAO, T. ${ }^{1,2}-$ LAI, R. F. ${ }^{3}-$ TANG, X. R. ${ }^{3}-$ TANG, Q. Y. ${ }^{4}-$ Hu, L. ${ }^{1,{ }^{*}}$ \\ ${ }^{1}$ College of Engineering, South China Agricultural University, Guangzhou 510642, PR China \\ ${ }^{2}$ Key Laboratory of Key Technology for South Agricultural Machine and Equipment \\ Ministry of Education, Guangzhou 510642, PR China
}

${ }^{3}$ Department of Crop Science and Technology, College of Agriculture, South China Agricultural University, Guangzhou 510642, PR China

${ }^{4}$ College of Agriculture, Hunan Agricultural University, Changsha 410128, PR China

"These authors have contributed equally to this work.

*Corresponding author

e-mail:lianhu@scau.edu.cn

(Received $9^{\text {th }}$ Mar 2019; accepted $1^{\text {st }}$ May 2019)

\begin{abstract}
Plough tillage had existed in Chinese agricultural history for a very long time. However, more and more farmers prefer to use the rotary machine to do the land preparation due to its ability to provide better soil fragmentation in recent years. The present study was conducted in order to study the effect of plough tillage on grain yield, quality and soil organic matter in ratooning rice systems, in Hunan Province, China, using a rice cultivar, Huanghuazhan as material and two tillage treatments were applied in present study. Conventional rotary tillage was named as CK and plough tillage was named as PT. The result showed that compared to CK, PT treatment not only could improve the grain yield of both main-crop rice and ratooning rice, but also increased the grinding quality and nutrition quality of grains in main-crop rice. Furthermore, higher soil organic matter was recorded under PT.
\end{abstract}

Keywords: ratooning rice, grain quality, yield, paddy soil, land preparation methods

\section{Introduction}

Ratooning rice is a special cultivation method in rice production. It has a long history in China which can be traced back to 1700 years ago (Min et al., 2017). It is characterized by cutting only about two-thirds of the upper part of the rice plant, collecting rice panicles, leaving behind one-third of the plant and root system, fertilization and cultivation, so that it can grow another season of rice. Normally, there will be some axillary buds when rice matures in the first season and after harvesting in the first season, they will be retained. On the basis of the original root system, these axillary buds will grow and heading again. After about 2 months, they will mature again and can be harvested (Rogé et al., 2016). Generally, the grain size of rice in the second season is smaller than that in the first season, but the number of panicles in the second season is higher than that in the first season (where the original panicle is cut, more than two panicles will grow), so the yield is not small.

The areas suitable for planting ratooning rice are mainly those where sunshine and heat are not enough to grow two-crop rice, but there are many areas where one-crop rice is planted. Because it grows again on the original roots, it saves the period from the first crop to the middle of the second crop (so it is called Ratooning rice, not Two-crop rice) in the second crop rice growing area. In this way, ratooning rice can be planted in areas with more than one 
season, thus increasing yield (Kupkanchanakul et al., 1990). At present, many areas in China, such as Sichuan and Fujian provinces, are experimenting to popularize this cultivation (Luzhou and $\mathrm{Hz}, 2000$ ). Thus, developing ratooning rice is an important task to ensure China's future food security.

As an important part in rice production, tillage is required to reduce the loss of water and fertilizers through excessive percolation and it also could decrease weeds and enhance nutrient availability (Alam et al., 2018). In Chinese agricultural history, there were two tillage methods including plough tillage and rotary tillage. Recently, because of the better soil fragmentation, most of framers are likely to use rotary machine to do the land preparation. However, excessive soil fragmentation under rotary tillage could induce the reduction in soil's ability to regulate water, air and heat (Abu-Hamdeh, 2000). The study of SUN (2017) revealed that compared to rotary tillage, plough tillage not only could improve the soil environment, but also could promote the root activity and the production of tobacco leaf.

In order to study the effect of plough tillage on ratooning rice system productivity and soil organic matter, present study was conducted in Hunan Province (major rice producing province in Central China) with the hypothesis that plough tillage could improve rice yield and grain quality in ratooning rice system.

\section{Materials and methods}

\section{Plant material and growing conditions}

A rice cultivar, Huanghuazhan, which having a growth period of 129-131 days and widely grown in Central China, was used in present experiment and planted at Hongshuo Farm, Datong Lake District, Yiyang, Hunan Province (29 08' N, 112 26’ E) in 2017. Before sowing, the seeds were soaked in water for $24 \mathrm{~h}$, germinated in manual climatic boxes for another $12 \mathrm{~h}$ and shade-dried. Then, the germinated seeds were sown in polyvinyl chloride trays for nursery raising. The experimental site enjoyed a subtropical monsoon climate and the air temperature during the experiment was shown in Figure 1. The soil type of paddy field is fluvo-aquic soil and mechanical composition is as follows: sand $(0.05 \sim 2 \mathrm{~mm})$ accounts for $34 \%$, silt $(0.002 \sim 0.05 \mathrm{~mm})$ for $56.7 \%$, clay $(0 \sim 0.002)$ for $9.3 \%$. It contained organic matter $29.30 \mathrm{~g} \mathrm{~kg}^{-1}$, total $\mathrm{N} 1.94 \mathrm{~g} \mathrm{~kg}^{-1}$, total P $1.31 \mathrm{~g} \mathrm{~kg}^{-1}$, and total $\mathrm{K} 26.70 \mathrm{~g} \mathrm{~kg}^{-1}$.

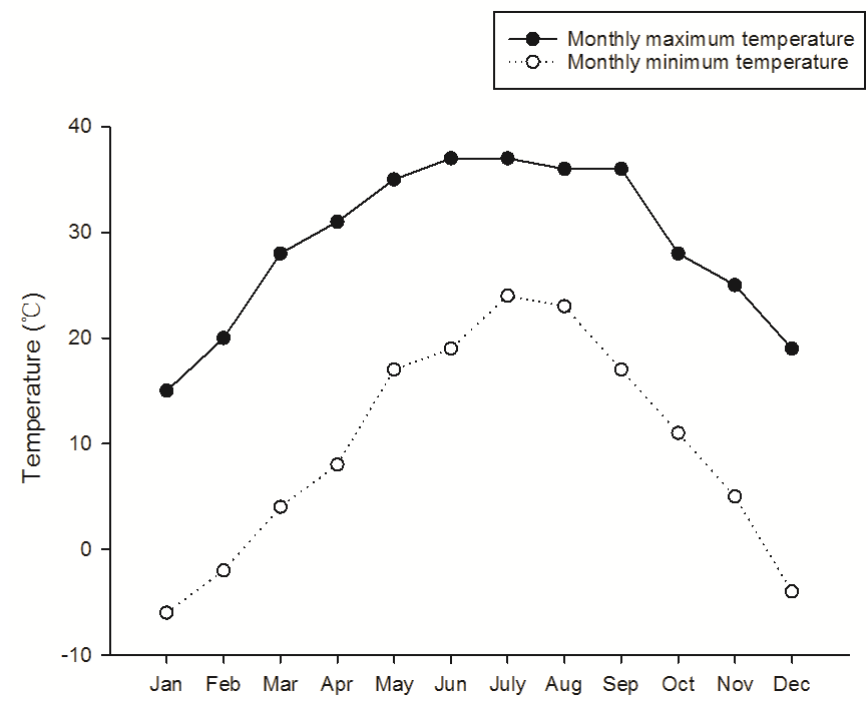

Figure 1. The temperature during the field experiment 


\section{Treatment description and sampling}

Two land preparations, plough tillage and rotary tillage were adopted in present study. We set rotary tillage as control (CK) and name plough tillage as PT.

CK: Before transplanting, the paddy field was puddle twice with rotary cultivator.

PT: Before transplanting, the paddy field was puddle twice with plough cultivator.

The treatments were arranged in randomized complete block design (RCBD) in triplicate with net plot size of $665 \mathrm{~m}^{2}$. After the harvest of main-crop rice and ratooning rice, five soil cores $(0-20 \mathrm{~cm}$ depth, $2 \mathrm{~cm}$ in diameter) were collected in each plot for the determination of soil organic matter.

\section{Estimation of soil organic matter}

The light fraction (LF) and heavy fraction (HF) of soil organic matter were separated using the method described by Camberdella and Elliott (1993). Briefly, $10 \mathrm{~g}$ of air-dried soil was homogenized with $30 \mathrm{ml} \mathrm{NaI}$ solution (gravity $1.8 \mathrm{~g} \mathrm{~cm}^{-3}$ ) in a $100 \mathrm{ml}$ centrifuge tube by shaking on a reciprocating shaker for $60 \mathrm{~min}$ at $200 \mathrm{rpm}$, after which it was centrifuged at $1000 \times \mathrm{g}$ for $15 \mathrm{~min}$. The LF, all floating material after centrifugation, was poured into a vacuum filter unit with a $0.45-\mu \mathrm{m}$ nylon film, and the material retained by the film was washed with $0.01 \mathrm{M} \mathrm{CaCl} 2$ and distilled water. This process was repeated three times. The HF remaining in the centrifuge tube was washed three times with ethanol to remove excess $\mathrm{NaI}$, after which it was washed twice with distilled water. Next, the LF and HF were dried at $60{ }^{\circ} \mathrm{C}$ for $48 \mathrm{~h}$, and then weighed and ground to pass through a $0.15-\mathrm{mm}$ sieve for organic determinations. The organic matter in LF and HF were determined by the wet oxidation method with $\mathrm{K} 2 \mathrm{Cr} 2 \mathrm{O} 7$ at 170 $180{ }^{\circ} \mathrm{C}$ (Zhao et al., 2016).

\section{Yield and yield related traits}

At maturity stage, the rice grains were harvested from ten-unit sampling area $\left(1 \mathrm{~m}^{2}\right)$ in each plot and then threshed by machine. The harvested grains were sun-dried and weighted in order to determinate the grain yield. Twenty hills of rice from different locations in each plot were sampled for estimate the average effective panicles number per hill. Then, eight hills representative plants were taken for estimation of the yield related traits.

\section{Grain quality}

After sun drying, grains were stored at room temperature for at least a month to determine grain quality components. About $1.0 \mathrm{~kg}$ rice grains from each treatment was taken from storage and brown rice rate was estimated using a rice huller (Jiangsu, China) while milled rice and head rice recovery rates were calculated by using a Jingmi testing rice grader (Zhejiang, China). Grains with chalkiness and chalkiness degree were estimated by using an SDE-A light box (Guangzhou, China) while an Infratec-1241 grain analyzer (FOSS-TECATOR) was used to determine the grain amylose and protein contents.

\section{Statistical analysis}

Data were analyzed on Statistix 8.1 (Analytical Software, Tallahassee, FL, USA) while differences among means were separated by using least significant difference 
(LSD) test at 5\% probability level. Graphical representation was conducted via Sigma Plot 14.0 (Systat Software Inc., California, USA).

\section{Results}

\section{Soil organic matter}

As shown in Figure 2, plough tillage significantly influenced the soil organic matter compared to CK. After the harvest of main-crop rice, $28.11 \%$ higher soil organic matter was recorded in PT than $\mathrm{CK}$. After the harvest of ratooning rice, compared to $\mathrm{CK}$, PT treatment increased soil organic matter by $19.56 \%$.

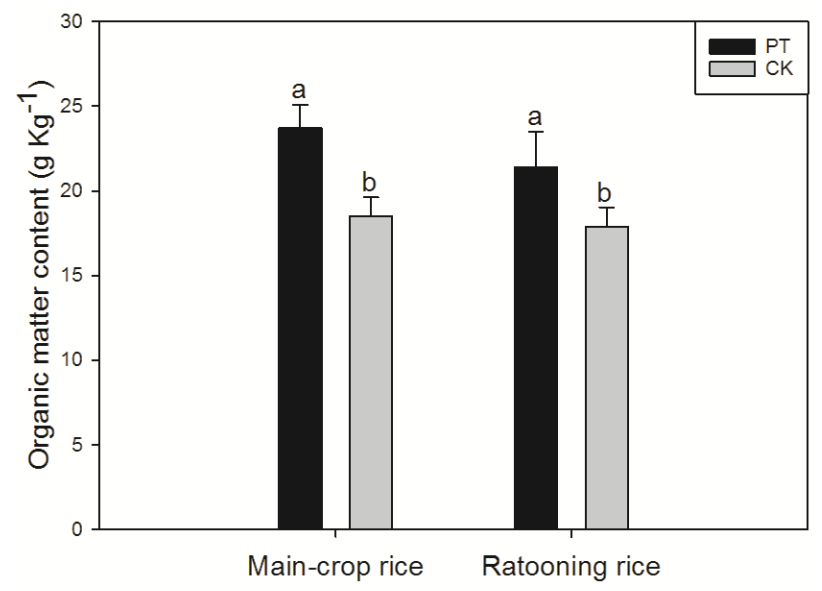

Figure 2. The effect of plough tillage on soil organic matter in ratooning rice system (Means sharing a common letter do not differ significantly at $(P \leq 0.05)$ according to least significant difference (LSD) test)

\section{Yield and yield related trails}

As shown in Table 1, plough tillage affected rice yield and related trails in ratooning rice system significantly. For main-crop rice, PT treatment increased panicle number, grains number and yield by $12.03,7.02$ and $10.99 \%$, respectively whilst there was no significant difference between PT and CK in both seed-setting rate and 1000-grain weight. For ratooning rice, compared to $\mathrm{CK}, 4.51,7.47,4.42$ and $4.72 \%$ higher panicle number, grains number, 1000-grain weight and yield were recorded in PT.

Table 1. The effect of plough tillage on rice yield and related trails in ratooning rice system

\begin{tabular}{c|c|c|c|c|c|c}
\hline & Treatment & $\begin{array}{c}\text { Panicle } \\
\text { number per } \\
\text { hill }\end{array}$ & $\begin{array}{c}\text { Grains } \\
\text { number per } \\
\text { panicle }\end{array}$ & $\begin{array}{c}\text { Seed- } \\
\text { setting } \\
\text { rate (\%) }\end{array}$ & $\begin{array}{c}\text { 1000-grain } \\
\text { weight (g) }\end{array}$ & Yield (t ha $\left.^{-2}\right)$ \\
\hline \multirow{2}{*}{ Main-crop rice } & PT & $326.97 \pm 16.78 \mathrm{a}$ & $128.56 \pm 3.76 \mathrm{a}$ & $86.60 \pm 3.71 \mathrm{a}$ & $22.82 \pm 0.65 \mathrm{a}$ & $7.50 \pm 0.39 \mathrm{a}$ \\
& CK & $291.87 \pm 15.99 \mathrm{~b}$ & $120.12 \pm 2.64 \mathrm{~b}$ & $85.61 \pm 2.29 \mathrm{a}$ & $22.42 \pm 1.03 \mathrm{a}$ & $6.76 \pm 0.41 \mathrm{~b}$ \\
\hline \multirow{2}{*}{ Ratooning rice } & PT & $355.94 \pm 8.65 \mathrm{a}$ & $56.36 \pm 1.48 \mathrm{a}$ & $78.51 \pm 1.90 \mathrm{a}$ & $22.69 \pm 0.43 \mathrm{a}$ & $3.46 \pm 0.06 \mathrm{a}$ \\
& $\mathrm{CK}$ & $340.70 \mathrm{~b} \pm 6.40 \mathrm{~b}$ & $52.44 \pm 0.71 \mathrm{~b}$ & $77.64 \pm 2.00 \mathrm{a}$ & $21.73 \pm 0.55 \mathrm{~b}$ & $3.30 \pm 0.07 \mathrm{~b}$ \\
\hline
\end{tabular}

Values sharing a common letter within a column do not differ significantly at $(\mathrm{P} \leq 0.05)$ according to least significant difference (LSD) test for both the years. The same as below 


\section{Grain quality}

As shown in Table 2, plough tillage affected grain quality in ratooning rice system significantly. For main-crop rice, compared to CK, PT treatment significantly increased brown rice rate, milled rice rate, head rice rate, crude protein content, amylose content and Akali value by $6.27,1.51,10.76,1.40,8.82$ and $2.92 \%$, respectively. Moreover, $25.64 \%$ lower chalky rice rate was recorded in PT treatment than CK. For ratooning rice, PT treatment increased both brown rice rate and Akali values significantly compared to $\mathrm{CK}$. However, there was remarkable difference between $\mathrm{CK}$ and PT in milled rice rate, head rice rate, crude protein content, amylose content, chalky rice rate and chalkiness.

Table 2. The effect of plough tillage on grain quality in ratooning rice system

\begin{tabular}{c|c|c|c|c|c|c|c|c|c}
\hline & Treatment & $\begin{array}{c}\text { Brown rice } \\
\text { rate (\%) }\end{array}$ & $\begin{array}{c}\text { Milled rice } \\
\text { rate (\%) }\end{array}$ & $\begin{array}{c}\text { Head rice } \\
\text { rate (\%) }\end{array}$ & $\begin{array}{c}\text { Crude } \\
\text { protein } \\
\text { content (\%) }\end{array}$ & $\begin{array}{c}\text { Amylose } \\
\text { content (\%) }\end{array}$ & $\begin{array}{c}\text { Akali } \\
\text { rate (\%) }\end{array}$ & $\begin{array}{c}\text { Chalky rice } \\
\text { (\%) }\end{array}$ \\
\hline $\begin{array}{c}\text { Main-crop } \\
\text { rice }\end{array}$ & PT & $73.13 \pm 0.34 \mathrm{a}$ & $64.60 \pm 0.33 \mathrm{a}$ & $42.52 \pm 0.05 \mathrm{a}$ & $7.26 \pm 0.03 \mathrm{a}$ & $18.50 \pm 0.04 \mathrm{a}$ & $5.86 \pm 0.07 \mathrm{a}$ & $19.33 \pm 0.88 \mathrm{~b}$ & $14.96 \pm 0.90 \mathrm{a}$ \\
\hline $\begin{array}{c}\text { Ratooning } \\
\text { rice }\end{array}$ & $\mathrm{CK}$ & $68.82 \pm 0.30 \mathrm{~b}$ & $63.64 \pm 0.16 \mathrm{~b}$ & $38.39 \pm 0.05 \mathrm{~b}$ & $7.16 \pm 0.03 \mathrm{~b}$ & $17.00 \pm 0.40 \mathrm{~b}$ & $5.70 \pm 0.05 \mathrm{~b}$ & $26.00 \pm 0.78 \mathrm{a}$ & $14.10 \pm 2.84 \mathrm{a}$ \\
\hline
\end{tabular}

\section{Correlation analysis}

As shown in Figure 3, there exited a significant positive correlation between rice yield and grain number. However, panicle number, seed-setting rate and grain weight all did not have significant correlation with the grain yield. Furthermore, there also existed a significant positive correlation between yield and soil organic matter (Fig. 4).
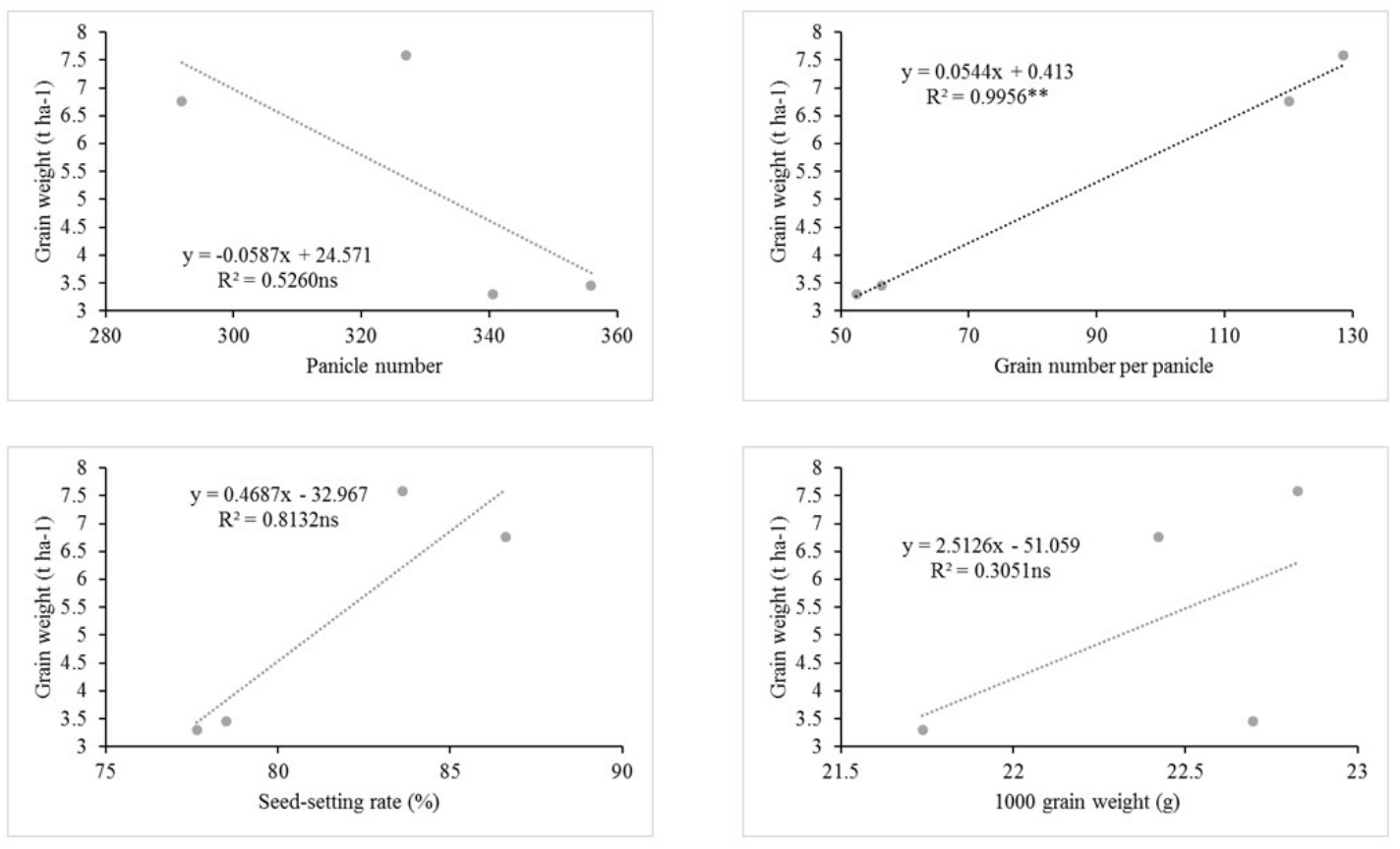

Figure 3. The correlation between yield related trails and yield in ratooning rice system 


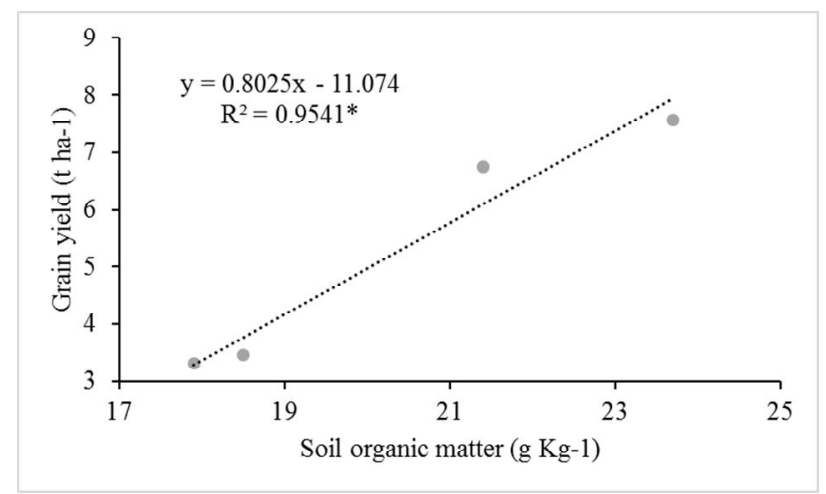

Figure 4. The correlation between yield and soil organic matter

\section{Discussion}

The development of ratooning rice is a vital way to achieve a full utilization of the solar-thermal resources in autumn and promote the profit of rice field. Previous study (Fu-Xian et al., 2015) already showed some key regulation technologies in ratooning rice cultivation such as varieties selection and fertilizer application. Present study revealed the effect of different tillage on yield, grain quality and soil organic matter in ratooning rice. Compared with conventional rotary tillage, plough tillage significantly increased the yields of both main-crop rice and ratooning rice. The increment in main crop rice yield could be explained by the improvement in panicle number and grain number. The increment in ratooning rice yield not only because of the enhancement of panicle number and grain number, but also due to the higher grain weight under plough tillage. Furthermore, we also observed a significant positive correlation between yield and soil organic matter which indicated that the improvement in soil organic matter due to plough tillage might be the direct reason of the yield increment. This result agreed with the study of Wei et al. (2016) who demonstrated that soil organic matter was an important factor which affected rice productivity significantly. Normally, the degree of soil fragmentation under rotary tillage is higher than plough tillage. But it also means the rotary tillage had rotary tillage destroys the soil more severely and excessive soil fragmentation can induce the decrement of biodiversity in farmland soil (Biswas et al., 2017). Our study showed that plough tillage was more suitable for ratooning rice cultivation because it not only improved the rice yield, but also had less soil fragmentation and improved the soil organic matter.

Moreover, in our study, we observed that plough tillage improved some grain quality attributes. Normally, rice price in market mostly depend on grain quality (Luo et al., 2018). For main-crop rice, plough tillage not only improved rice grinding quality such as brown rice rate, milled rice and head rice rate, but also increased the grain nutrition quality such as protein and amylose content. The increments in grain quality might because the plough tillage improved rice growth and development.

\section{Conclusion}

In ratooning rice system, compared to rotary tillage, plough tillage not only could improve the grain yield of both main-crop rice and ratooning rice, but also increased the grinding quality and nutrition quality of grains in main-crop rice. Moreover, higher soil 
organic matter was recorded in plough tillage than rotary tillage. In order to explore the mechanism of how tillage affects ratooning rice performance, further investigation should be at the field trials.

Acknowledgements. This study was supported by the National Key Research and Development Program of China (2016YFD0700301) and National Natural Science Foundation of China (31601225).

\section{REFERENCES}

[1] Abu-Hamdeh, N. H. (2000): Effect of tillage treatments on soil thermal conductivity for some Jordanian clay loam and loam soils. - Soil \& Tillage Research 56: 145-151.

[2] Alam, M. J., Humphreys, E., Sarkar, M. A. R., Yadav, S. (2018): Comparison of dry seeded and puddled transplanted rainy season rice on the High Ganges River Floodplain of Bangladesh. - European Journal of Agronomy 96: 120-130.

[3] Biswas, S., Hazra, G. C., Purakayastha, T. J., Saha, N., Mitran, T., Roy, S. S., Basak, N., Mandal, B. (2017): Establishment of critical limits of indicators and indices of soil quality in rice-rice cropping systems under different soil orders. - Geoderma 292: 34-48.

[4] Cambardella, C. A., Elliott, E. T. (1993): Methods for physical separation and characterization of soil organic matter fractions. - Geoderma 56: 449-457.

[5] Fu-Xian, X. U., Xiong, H., Zhang, L., Zhu, Y. C., Jiang, P., Guo, X. Y., Liu, M. (2015): Progress in research of yield formation of ratooning rice and its high-yielding key regulation technologies. - Scientia Agricultura Sinica 9: 1702-1717.

[6] Kupkanchanakul, T., Vergara, B. S., Kupkanchanakul, K. (1990): Ratooning ability and potential herbage production from ratoon crops of rice cultivars. - International Rice Research Newsletter 15(5): 10.

[7] Luo, H. W., Wang, Z. M., Chen, Y. Y., Zheng, A. X., Chen, Y. L., Du, P., Mao, T., Meng, S. B., Tang, X. R. (2018): The effects of different temperatures on the biosynthesis of grain protein in rice at filling stage. - Applied Ecology and Environmental Research 16: 8017-8027.

[8] Luzhou, K. M. Hz, W. (2000): Achievements and developments of ratooning rice in South of China. - Acta Agronomica Sinica 26(3): 1-5.

[9] Min, X. I., Wenge, W. U., Wang, J., Wang, H., Chen, G., Youzun, X. U. (2017): Study on formation of grain yield differences in ratooning rice cultivation. - Acta Agriculturae Boreali-Sinica 32(1): 104-110.

[10] Rogé, P., Snapp, S., Kakwera, M. N., Mungai, L., Jambo, I., Peter, B. (2016): Ratooning and perennial staple crops in Malawi. A review. - Agronomy for Sustainable Development 36: 50.

[11] Sun Jingguo, W. C. C. Z. (2017): The influence of different tillage on soil and flue-cured tobacco. - Journal of Hubei University (Natural Science) 39: 299-304.

[12] Wei, W., Yun, Y., Jian, C., Christie, P., Zhang, F., Fan, M. (2016): Effects of combined application of organic amendments and fertilizers on crop yield and soil organic matter: An integrated analysis of long-term experiments. - Agriculture Ecosystems \& Environment 225: 86-92.

[13] Zhao, S., Li, K., Wei, Z., Qiu, S., Huang, S., Ping, H. (2016): Changes in soil microbial community, enzyme activities and organic matter fractions under long-term straw return in north-central China. - Agriculture Ecosystems \& Environment 216: 82-88. 